\title{
Staging the unsayable: debbie tucker green's political theatre
}

Article

Accepted Version

Abram, N. (2014) Staging the unsayable: debbie tucker green's political theatre. Journal of Contemporary Drama in English, 2 (12). pp. 113-130. ISSN 2195-0156 doi: https://doi.org/10.1515/jcde-2014-0009 Available at https://centaur.reading.ac.uk/36653/

It is advisable to refer to the publisher's version if you intend to cite from the work. See Guidance on citing.

To link to this article DOI: http://dx.doi.org/10.1515/jcde-2014-0009

Publisher: De Gruyter

All outputs in CentAUR are protected by Intellectual Property Rights law, including copyright law. Copyright and IPR is retained by the creators or other copyright holders. Terms and conditions for use of this material are defined in the End User Agreement.

\section{www.reading.ac.uk/centaur}

\section{CentAUR}

Central Archive at the University of Reading

Reading's research outputs online 


\title{
Staging the unsayable: debbie tucker green's political theatre
}

\author{
Nicola Abram
}

debbie tucker green is one of the most stylistically innovative and politically engaged playwrights at work in Britain today. Her prolific output is widely recognised in discussions of contemporary black British theatre, where she is often named alongside Kwame KweiArmah and Roy Williams as the leading playwrights of their generation. ${ }^{1}$ Moreover, she has become a figurehead for new British playwriting more broadly, as evinced by her inclusion in Aleks Sierz' Rewriting the Nation: British Theatre Today (2011). Yet this energetic acclaim was preceded by a period of critical questioning; early reviewers responded indignantly to her subversion of conventional plot structures, highly stylised use of language and assuredly sparse stage design. Many saw these features as a failure to fulfil the demands of the dramatic medium; some hesitated to use the term "play" to classify her work. One critic, receiving her drama as an aural rather than visual or embodied experience, claimed that she would "find a happier home on [BBC] Radio 3" (I. Johns). In another particularly piqued response, reviewer Dominic Cavendish parodied the demotic voice in which tucker green's characters speak: "I don't do silence, innit" (251). This invocation of silence - or, rather, its absence - is intriguing. Cavendish is right that tucker green's plays are marked by chaotic dialogue: incessant repetition, overlap and interruption. Yet, amidst this proliferation of speech, much remains unsaid. This article examines tucker green's use of silence and unintelligible sound to negotiate of political subject matter. I will comment on four productions: born bad, stoning mary, generations, and random. These span tucker green's career to date.

born bad, which won tucker green the 2004 Olivier Award for Most Promising Newcomer, depicts a family fractured by abuse, jealousy, and denial. The "dawta" (tucker green's manipulation of standard grammar and spelling extends to her characters' names, as

\footnotetext{
1 tucker green's first produced play, two women (Soho Theatre, 2000), was followed by dirty butterfly (Soho, 2003; Young Vic, 2008), born bad (Hampstead Theatre, 2003), stoning mary (Royal Court Theatre, 2005), trade (RSC New Work Festival, Stratford, 2004), generations (National Theatre, 2005; Young Vic, 2007), random (Royal Court 2008; tour 2010), truth and reconciliation (Royal Court, 2011) and nut (National Theatre, 2013). Her theatre writing is complemented by several radio plays, and she has also revised random into a screenplay for Hillbilly and Film 4 (2011).
} 
well as the capitalisation of her own) is motivated to uncover what long years of silence have concealed: the incestuous abuse she was subjected to as a child. ${ }^{2}$ In order to do so she approaches each family member in turn. The questioning of her two sisters centres on their mother's complicity, while it later emerges that Brother was also abused - though a compulsion to protect his mother makes him rather reluctant to talk. The father sits as an eerie backdrop to these heated conversations. He remains silent except for a few brief exchanges: a refusal to speak to his son, a command to Dawta to sit, a taunt to his wife, and the play's arresting final line, revealing the mother's responsibility for Dawta's abuse: "You made the wrong choice" (50).

The 2003 Hampstead Theatre production of born bad did not attempt a naturalistic depiction of a family home. The set consisted of simple white screens, surrounding piles of wooden chairs from which the characters gradually arranged a circle. This cyclical aesthetic was to recur in the rotating disc of sand in 2004's trade; the arrangement democratically refuses to privilege any one character, instead emphasising the connections between them. Similarly, the cyclical configuration of born bad makes the complex dynamics between family members assume a vital visual importance. In one scene Dawta stands outside the circle, as an emblem of her exclusion from the family unit; in the next she sits on the floor between her father's legs, in a chilling vignette of the physical and psychological control he exercises over her. tucker green's stage directions dictate that no character leaves once onstage, meaning every painful, private conversation is conducted in front of silent sibling and filial observers. Although such characters may stand unseen in the shadows, their empty chairs remain onstage as a surrogate presence. As well as a reminder of the specific character who positioned it, each chair is also mimetic of the human spine, weight, and sentient awareness, functioning as a "projection of the human body" (Scarry 289). The persistent presence of each character symbolised in the congregation of empty chairs asserts that the damaging family relationships reverberate beyond the few characters interacting at any given time. Significantly, then, tucker green comments most audibly on the play's central issue, incestuous abuse, through form. She denaturalises the characters' presence using substitute objects, silently staging her argument.

\footnotetext{
${ }^{2}$ The topic of sexual abuse is also treated in tucker green's first, and unpublished, play, She Three, held in manuscript at the Theatre and Performance Collections of the Victoria and Albert Museum. Here, too, we find a group of three girls, though they are friends rather than the sisters we meet in born bad. tucker green's synopsis states: "Bev has been abused, which her friends had suspected, but to Bev's dismay had never questioned". She Three also anticipates stoning mary and generations in addressing the effects of HIV/AIDS on the family.
} 
In contrast with the dramatic unity and chronological linearity shaping that earlier play, stoning mary juxtaposes three stories without framing or explanation: an AIDSsuffering husband and wife clash over a single prescription; a mother and father fight over the memory of their absent son; a young woman visits her sister in prison. Eventually, it becomes clear that these scenes form discrete moments in a single story: the husband and wife are the parents of the sisters, the younger of whom has been imprisoned for avenging their death at the hands of a child soldier, who is the mother and father's absent son. As in born bad, these intertwined scenes focus on familial relations - though in stoning mary the horrors result from contemporary conditions (the HIV/AIDS crisis, child militia, punishment by stoning) rather than being inflicted from within.

The invocation of these contextual features is significant in stoning mary, as so few of tucker green's productions identify a precise geopolitical location. In those that do make such gestures, tucker green is often anxious to attend to topics beyond black Britain: trade is set in an unspecified Caribbean resort, while generations makes implicit reference to South Africa. stoning mary, meanwhile, stipulates a white cast and coyly mandates that the story is "set in the country it is performed in" (2). Although some critics complained that the bare stage of the Royal Court's 2005 production failed to convince them of this specified setting, the visual code of the actors' bodies and the aural code of their Estuary accents responded to tucker green's intentions. By transposing recognisably - indeed, stereotypically - African issues across continents into a British setting, tucker green makes the trauma of such atrocities more tangible for her imagined white liberal audience (Interview 2005). This transpositional impulse anticipates her collaboration on The Laws of War, which saw England portrayed as "a hell of displaced people, rape, child soldiers and warlord militias" (Royal Court). Ken Urban has remarked on the political currency of adopting such a strategy, citing erstwhile Prime Minister Tony Blair's comments at the World Economic Forum earlier in the year that stoning mary was staged: "If what is happening in Africa today were happening in any other part of the world, there would be such a scandal and clamour that governments would be falling over themselves to act in response" (52). Indeed, the intention to elicit an active response was literalised in The Laws of War; the play was a fundraising event for Human Rights Watch. In a related gesture, also directed towards producing audience engagement, the production design of born bad replaced the lower stalls of the Royal Court's main space with a large, oval, promenade stage. This reconfiguration mirrored the transposition of African stories to a British stage, as the characters invaded the physical space usually occupied by the 
audience. Audience members, already displaced from their usual position, were thereby guided towards being moved in the word's other sense, emotionally.

The third play addressed here, generations, sees another family suffer under contexts beyond their control. The National Theatre's 2005 production was set around a pot bubbling on a stove; this gesture towards theatrical naturalism was made by director Sacha Wares. This play sees three generations of black South Africans tease each other over their cooking abilities and courtship rituals, while an African choir periodically summons the actors from the stage without explanation, one by one, until only the grandparents remain to lament the loss of the others. The dialogue is cyclical, as the gradually diminishing cast repeat the same stunted conversation with each scene. Framing the play, the choir sings a prologue and epilogue reciting and commiserating a long list of African names: "Another leaves us, another has gone" (67). These names locate the production geographically, tempting its audience to speculate on the nature of the crisis that occasions such a significant loss - we might infer AIDS, as in stoning mary, though this is never stated explicitly. In the absence of direct exposition, the audience's understanding is mediated through the family's pain at their personal suffering. For instance, one character sets a place at the dinner table for youngest girl, only to realise that she, too, has silently departed (Letts 2007). As in born bad, it is the unspoken that is most telling. And, again, this takes the form of a visible friction between absent and present bodies.

The latest of the four selected plays, random, follows the details of a family morning punctuated by alarm clocks, sibling bickering and burnt porridge. This play presents black Britain at its most mundane until, unexpectedly, these familiar rituals are interrupted by news of the son/brother's murder. Once again, the specificity of the organising event is withheld: was Brother the victim of a racially motivated attack? Perhaps he was embroiled in urban gang politics? Such questions remain unasked and unanswered, as the climactic moment itself is not shown. Despite violent teenage crime being of current concern - I might again quote Tony Blair, whose comments on black violence informed Lynette Goddard's discussion of random ('Death' 299) - tucker green insists on presenting the effects on individuals rather than attempting a social diagnosis. Complementing this unusual treatment of the theme, random takes the experimental form of a monologue. tucker green specifies that a single black actress plays multiple parts: family members, work colleagues, schoolteacher, school friends and policemen. Such formal innovations distinguish tucker green's work from the self-consciously realist aesthetic that attends to much contemporary black British playwriting and prose, including her peers in theatre Kwame Kwei-Armah and Roy Williams. random, 
like born bad, stoning mary and generations, mobilises creative stage techniques to avoid being dismissed as an unambitious tale of the "ghetto" (L. Johns).

While tucker green traverses themes of national and international importance, her focus never wavers from staging the family in all its complexities. This concern for human relationships is emphasised in her propensity not to use proper nouns. "Brother", "Mum" and others are identified by their multiple relationships with one another rather than being named as independent individuals. The eponymous "Mary", of stoning mary, enjoys a rare designation, although this particular name nonetheless retains a representative quality. Lynette Goddard has suggested that the lack of names avoids limiting the plays to a particular ethnic context (2010), and instead issues an appeal to any spectator to imagine their own "Mum" or "Junior Sister" involved in the horrors onstage. I would add that the absence of proper names mimics the dynamics of real relational dialogue, which assumes the attention of its interlocutors rather than hailing them by name, refracting the spectators' experience of the play through the characters' participation in the family.

This centrality of the family anchors tucker green's exploration of global themes. In generations, for example, the distortion of relationships indexes the damaging wider cultural crisis that may be AIDS. As the number of characters diminishes, those remaining begin to adopt and adapt the words of their earlier companions. For instance, Junior Sister's address to her mother - "Mummy, he asked her if she could cook" (69) - is later echoed by Mum, when the younger generation are gone. Having lost her own offspring Mum is returned to being a daughter herself, rather than occupying the two-directional position of being both mother and daughter. Attention is rerouted back towards the preceding generation, rather than onwards towards the future as represented by the younger. The usual transmission of cultural and family heritage to and through the succeeding generations is reversed, as the old are forced to remember and commemorate the absent young. This theme of generational loss is formally enacted in the lack of structural development, as the play itself never matures. Instead, as it returns with each new scene to the same discussion, generations aestheticises the theme of premature death. Just as the younger characters gradually disappear offstage, as their lives are cut short, so the play itself is repeatedly stunted, beginning again a conversation that will not endure. Finally, Grandma and Grandad are left alone, rehearsing the tales of the lost generations. Their dialogue circles obstinately around the superficial topic of cooking, rendering the play strangely static, in a manner that recalls Samuel Beckett's absurdist drama. For the characters in generations, speech takes on a phatic function as an increasingly anxious 
attempt to secure familial communion. Despite the proliferation of verbal noise, the busy dialogue in generations fails to produce meaning.

\section{"You got nothing to say then?" Silence as dramatic form}

Clearly, the urgency of tucker green's chosen subject matter is not matched by an aesthetic of exposition. The contextual issues which might describe her plays - murder, AIDS, poverty, tribal conflict, domestic and incestuous abuse - are rarely named between the covers of her slim volumes (though paratextual material sometimes offers a prompt, as in the captions adorning the flyers for random's 2010 national tour: "Death never used to be for the young") or brought onstage. In stoning mary, the acts of violence - the child soldier's attack on Husband and Wife, and the public torture of his killer - are confined to the blackouts between scenes. Characteristically, tucker green stages the effects of contextual crises without endorsing an unpalatable description of the contexts themselves. In born bad the most explicit evocation of sexual abuse is in Sister 1's memory of praying for Dawta "to not fall pregnant" (12). When the plot then requires Brother to tell of his own experience of abuse, the play again falls silent; between scenes twelve and thirteen, the dialogue leaps from Mum's naïve enquiry, “Ask our son what?", to Brother's numbed conclusion: "So. / Now you know" (489). tucker green's formal refusal to give direct statements seems to oppose Dawta's quest to hear her childhood abuse articulated by her family. In born bad, then, tucker green demonstrates the therapeutic need to give voice to trauma while simultaneously showing the difficulty of finding a suitable form of expression.

However, one of the few occasions when such issues are announced occurs in stoning mary. The Royal Court's 2005 production named each scene with a subtitle projected in white onto the floor and rear wall, variously: "The AIDS Genocide. The Prescription", "The Child Soldier", and "Stoning Mary". This technique perhaps responds to tucker green's specification of white actors, as the specified topics are so welded in the popular imagination with other kinds of bodies that audience comprehension might suffer. Deirdre Osborne has pursued a less materialist explanation of the titling; she experiences its effects as Brechtian, with the projected headings functioning as "a subliminal reminder of white Western imperial culpability for the tragedies dramatised" (43). The invasive presentation of the titles certainly aligns with such a politicised aesthetic of distantiation. It restricts the possibility of emotional identification with the characters and thereby limits catharsis, invoking a cognitive rather than affective response. 
Yet, the stark titles adorning stoning mary clash both with tucker green's preference for implication over exposition, and with her tendency towards humanising her subject matter. I therefore read these subtitles as a critique of Brecht's influence on political theatre forms. The play deliberately juxtaposes the distancing spectacle of the headlines with the human complexities of each subsequent dramatic scene. The text is privileged temporally, as the titles precede each scene, and visually, appearing on an otherwise bare stage. I venture that this arrangement actually limits audience engagement: not only do the titles fail to articulate anything of real significance, such as answering questions about human cause and cost, but their ostensible clarity stunts the desire to ask such questions at all. Ultimately, these announcements preclude a politicised response. I therefore read the subtitles as a provocative juxtaposition of words alongside dramatic action, as the power of tucker green's play capitalises - despite her predilection for all things lower case - precisely on what remains unsaid.

Each play's reluctance to disclose its central concern corresponds on a macro level with the disjointed interactions of tucker green's feisty characters. Speech routinely appears as disconnected fragments, with sentences left unfinished or lacking vital elements. The absence of nouns, those "deadly truths" (Coghlan) that would name the tragedies the characters face, conceals the plays' participation in some of the great debates of our time. Alexandra Coghlan visualises tucker green's language as "in its death-throes, contorting, writhing and twisting every which-way", in a fevered attempt to escape its bondage to meaning. Coghlan's compelling imagery here personifies language, understanding that tucker green's words aim to approximate the essence of human interaction. Her characters simultaneously vie to speak and refuse to listen. Ensuring this frantic delivery, tucker green frequently specifies overlapping dialogue, typographically denoted here (as in the published scripts) by a slash:

$\begin{array}{ll}\text { GRANDMA } & \text { You were a / bad learner - } \\ \text { GRANDAD } & \text { You couldn't cook } \\ \text { MUM } & \text { Course she / could cook - } \\ \text { GRANDMA } & \text { I couldn't cook? } \\ \text { MUM } & \text { Mummy could / cook } \\ \text { GRANDMA } & \text { I couldn't cook? } \\ \text { (generations 85) } & \end{array}$

The effect in production differs from the appearance of the text in publication. Despite tucker green's careful choreography of overlap the eye reads the printed script as sequential, unable to accommodate a simultaneous plurality of voices. Yet, onstage, the conversation reproduced in print above becomes bickering between Grandma and Grandad, while Mum's contributions 
are repeatedly obscured. The effect of such interruption alters again when the attempted communication is between just two participants, as in this extract from born bad:

$\begin{array}{ll}\text { BROTHER } & \text { What's your problem? } \\ \text { SISTER 2 } & \text { I don't / have a } \\ \text { BROTHER } & \text { what is your problem? } \\ \text { SISTER 2 } & \text { I don't got a problem thank you } \\ \text { BROTHER } & \text { I think you have } \\ \text { SISTER 2 } & \text { which is the problem / you've got } \\ \text { BROTHER } & \text { you're / not } \\ \text { SISTER 2 } & \text { the problem you've got } \\ \text { BROTHER } & \text { you're not / my } \\ \text { SISTER 2 } & \text { the problem you've got with me. } \\ \text { BROTHER } & \text { You're not my problem you're not - } \\ \text { (35) } & \end{array}$

Their battle to secure the other's attention means that Brother and Sister 2 both fail to complete their sentences and so must repeat and recycle their attempts to express themselves. Strikingly, though, they are able to anticipate each other's comments, and so the conversation continues to progress. This unlikely directionality is evident in the previously cited dialogue between Grandma and Grandad, too, where the latter responds to the former's accusation ("You were a / bad learner") with his own jibe ("You couldn't cook"), even before the insult is completed. Such a rapid stacking of dialogue suggests the recital of a familiar conversation. The impact of such scenes, as hyper-realistic demonstrations of human interaction, rests in the fact of failed communication between characters rather than in the specific content of their unheard contributions.

The phenomenon of overlapping dialogue is amplified by the characters' tendency to truncate or conjoin their own words. Dropping the final 'g' in gerunds ("remembrin", "askin", "nuthin", "ignorin") facilitates the speed of the speech, while refusing to use an apostrophe to indicate missing letters is an orthographic assertion of the validity of this new urban diction - the same linguistic resistance occurs in other Creole and patois cultures. Lexical contractions such as "butcha" for "but you", "whatchu" for "what are you", and "tryinta" for "trying to" also effect a naturalistic portrayal of urban speech by denoting its speed. ${ }^{3}$ Indeed, tucker green declares her intention to mimic demotic rhythms when justifying another linguistic affectation, her use of repetition. She even enacts the trait in her explanation: "Listen to a group of kids - just repeat and repeat and repeat" (Interview 2003). Like the anxious repetition of statements, linguistic contractions and truncations are both

\footnotetext{
${ }^{3}$ Gabriele Griffin identifies a similar technique in the work of African American playwright and poet Ntozake Shange. Griffin cites "usedta" ("used to"), "cda" ("could have"), and "hadda" ("had a") as examples (35).
} 
calculated to expedite expression in circumstances where a character's speech are threatened by the potential or actual entry of another voice.

The characters' silencing of one another by excessive speech is accompanied by the extended silences that pepper tucker green's plays. ${ }^{4}$ It is not uncommon to encounter a page in the playscript as bare as the following:
MUM
They took him.
They did.
DAD
MUM
MUM
MUM
DAD
MUM
Wash it now ...
DAD
(stoning mary 35)
Run your hands over his number one now.

Dad fails to respond to Mum's opening comment, which provokes a protracted silence from Mum in turn. The naming in the playscript does not simply measure the length of time for which the named character is to keep quiet, as of course the silence is shared by both actors onstage. Rather, the attribution is meaningful: an "eloquent silence" (Sifianou 65). Any given suspension of speech may speak of something specific going unsaid, or else may function as a "feedback mechanism" (Agyekum 34), variously articulating a manifestation of offence, a confession of powerlessness, or an act of capitulation.

These attributed absences of sound invoke a visual register, as tucker green choreographs attention towards particular characters in a specified order. Such verbal silences point towards a "surrogate language" of the body, which communicates "in lieu" of spoken words (Agyekum 43). In this filmic aesthetic, actors are required to express their ownership and interpretation of the silence kinaesthetically. tucker green thus combines and contrasts two representational modes: visual and aural. Indeed, these two registers are linked within the created worlds of the plays themselves: the failure to speak is often accompanied by a failure to look.

An agonising scene between Husband and Wife illustrates the synchronous failure of verbal and visual communication in stoning mary. Attempts at psychological manipulation

\footnotetext{
${ }^{4}$ Demonstrating a further transatlantic dimension to black British literary criticism, and perhaps also to creative influence, tucker green's specification of active silences between characters has been likened in style to African American playwright Suzan-Lori Parks (Osborne 37).
} 
manifest in the pair's silence, coupled with their increasingly creative ways to avoid looking at one another:

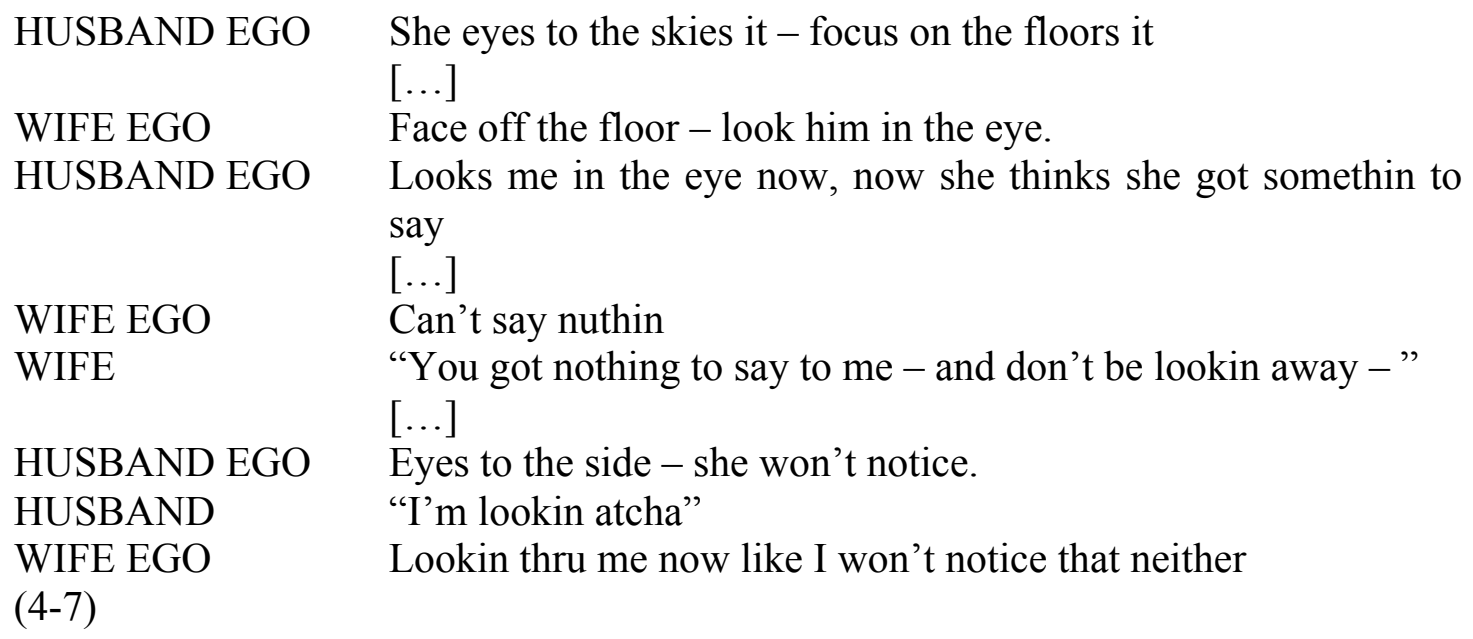

This scene sees both Husband and Wife accompanied by an "Ego", an embodied representation of an inner consciousness delivering that which is not spoken or speakable aloud. In this portion of the play, then, silence is neither a typographical event nor an audible one but is implied in the diegetic world of the disintegrating relationship through the fact of the two Ego characters' speech. Although this is distinguished in print from the externalised speech of the Wife and Husband by the latter's enclosure in quotation marks, both registers are experienced equally by a live audience. The couple's silence is thus implied at the very moment it is undone by the Egos' utterances. Unlike the dense and frenetic dialogue in tucker green's other plays, the Egos do not quash the other characters' attempts to speak but their silences. The Egos also function to interpret the implied silences between the main characters. This role is particularly valuable to the reader of the published script, who lacks access to the characters' non-verbal communication. Through the Egos, tucker green makes her characters' body language legible, embedding her stage directions within the playtext itself.

In random, too, the characters' silence is sometimes elucidated by the playwright herself. In these instances she provides a meaning that is intended but goes unspoken, as in the parentheses below:

Dad tryin to say somethin.

Dad's tryin to say something

But

... nu'un won't [come out]...

Dad's silence is his defining characteristic throughout this play. His daughter knows him as "the kinda dad who... / don't say much. / Unless he have to" (18). Yet, here he owes his silence to faltering speech rather than a positive choice for linguistic economy. This new kind 
of silence implies the inability of language to mark the magnitude of his grief. This silence leaks into his daughter's stunted comment, where parentheses formally enact the failure of the very language she describes. The same scene continues with the daughter's confession of an awkward, almost voyeuristic vision:

I watch.

Watch him.

... He's embarrassed.

I watch his embarrassment.

I can't look away.

Daughter literally looks to Dad, perhaps for comfort or perhaps in surprise at his uncharacteristically emotional response. She both speaks and seeks to be seen. Conversely, her father cannot bring himself to say a word, and "still ent stopped / lookin away" when they arrive home from the mortuary (38).

born bad, too, embeds a correlation between speech and sight. It opens with Dawta directly addressing her father, in a short and typically elliptical scene. Since it is repeated three times, her demand that he should admit his guilt - 'Say it' (3) - mirrors the Biblical Peter's denial of Christ - another decisive moment in a relationship. During this address to her "Daddy" (ibid.), Dawta tries anxiously to secure eye contact, demonstrating that her longed-for communication is not only verbal but also corresponds to bodily interaction. Although the scene closes with him looking at her, he remains silent - as does tucker green. It is not clear whether Dawta sought a confession, an explanation, an expression of love or an apology, nor whether her unnamed need is met. Immediately after this scene, we find a similar interaction between Dawta and her mother. Here, Dawta repeatedly and violently spits "bitch" at the woman she believes was complicit in her abuse. Mum, refusing to listen to her daughter's accusations - "Don't say that" (4) - also resists looking at her: "You got nothing I need to see" (5). Mum's retreat from the evidence enables her to continue her wilful denial. Her refusal to witness (to) her daughter's abuse is both visual and verbal; she will neither acknowledge it nor testify, neither see nor speak. Clearly, tucker green's silence is not simply an aesthetic tic. The political weight of her plays is borne by her discomfiting insistence on failed communication.

\section{"Say it. Say it." Silence as moral failure}

As well as informing series of formal techniques, silence also appears as a theme in tucker green's constructed worlds. Characters regularly indict others' failure to speak up. One such 
scene in stoning mary sees the eponymous young woman berate the pitiful number of signatures on the petition she needs to escape her punishment. In an unusually uninterrupted monologue, Mary laments:

So what happened to the womanist bitches?

... The feminist bitches?

... The professional bitches.

What happened to them?

What about the burn their bra bitches?

The black bitches

the rootsical bitches

the white the brown bitches

the right-on bitches

what about them?

What happened to the mainstream bitches?

The rebel bitches

the underground bitches

what about - how bout -

the bitches that support other bitches?

$(61-2)$

Mary's invective has been seen as typical of tucker green's suffering characters: they rarely react directly to their abusers or confront the oppressive social systems that constrain them, but instead address women's failure to support one another. Marissia Fragkou reads this as part of tucker green's humanising efforts; refracting political issues through these personal interactions "highlights our vulnerability and dependence on others" (Fragkou). Mary's speech is of vital significance to stoning mary - indeed, it was excerpted on the back cover of the publication - and perhaps to tucker green's canon as a whole. Incarcerated pending her punishment, the young woman asks where her supporters are; her paying spectators, who have gathered around a horseshoe-shaped stage piled with rocks, are pointedly invited to consider their next move.

For Dawta in born bad, a similar lack of peer support becomes apparent as Sister 1 recounts her childhood prayers. Being directed heavenward, this speech failed to respond appropriately to her knowledge of her sister's abuse, the meaning of the "empty bed" (12). Meanwhile, Sister 2 fails to respond at all, vowing ignorance: "don't ask me nuthin" (13). Her active refusal to remember even calls attention to the lack of other witnesses: "Hear what [...] The silence a no-one sayin it" (19). After Brother's murder in random, Sister's distress is directed at a similar silence:

I lissen and I hear ... 


\section{(Silence.)}

I hear - an juss get -

(Silence.)

Whole heap a witness

Polices say.

Whole heap a somebodies

on street.

Saw.

Whole heap a peeps

on road

was present.

But I listen -

hard -

an' still I hear...

\section{(Silence.)}

Silence shoutin the loudest.

Cos it seem that

now no one wanna witness

what happened

to my Brother.

(44-45)

Again, print fails, as we read "Silence" rather than hear the crushing quiet audible in the auditorium, the public response to Sister's appeal. The audience is offered no shelter from her accusations, as the unitary performer's gaze is directed offstage. If spectators remain quiet, trained in contemporary British theatrical convention, they become complicit in the very failure to speak that Sister derides. Silence, then, acquires a perlocutionary force: it demands action.

This strategic silencing of audiences is specific and delimited, imagining a certain profile of spectator. More than one critic has confessed to not following tucker green's dialogue, denouncing the combination of speed, rhythm, and patois as "unintelligible" (de Jongh), "a bit mannered" (Shore), and "at the expense of clarity" (Letts 2005). That these comments come exclusively from male critics, with unashamedly "middle-class, white ear[s]" (Letts 2008) - notwithstanding the protests that their lack of comprehension is attributable simply to being over the age of twenty (Nathan) - testifies to the limited aesthetic referents operative in mainstream theatre reviewing (Osborne 36). By refusing to inhabit extant theatrical models, tucker green actively limits the traditional theatre-going public's ability to 
hear. Such spectators are therefore unable to fully witness, and so are pointedly indicted for their specific failure to act.

Alongside this affront to the privileged, random curates other silences for other audiences. Critic Aleks Sierz reported that school groups were noticeably quieter in the second half, after enthusiastically cheering the representations of youth culture in the first (2008). Another critic commented on the "pin-drop silence" (Billington), while director Sacha Wares also remarked on the students' attention. By structuring random in two distinct halves, which induce a marked shift in school-aged spectators' behaviour, tucker green positions these audiences to consider their access to voice and their responsibility to speak up.

Beyond any demographic specificity, tucker green elides the possibility of full comprehension for all audiences through her elliptical style. The mundane content of her characters' utterances belies the precision and detail of this technique. For instance, she crowds certain phonemes together so that the aural quality of her characters' words overrides their semantic work. In the following extract from generations, Boyfriend's persistent and protracted alliteration of "c" exaggerates the impact of an ultimately insignificant statement:

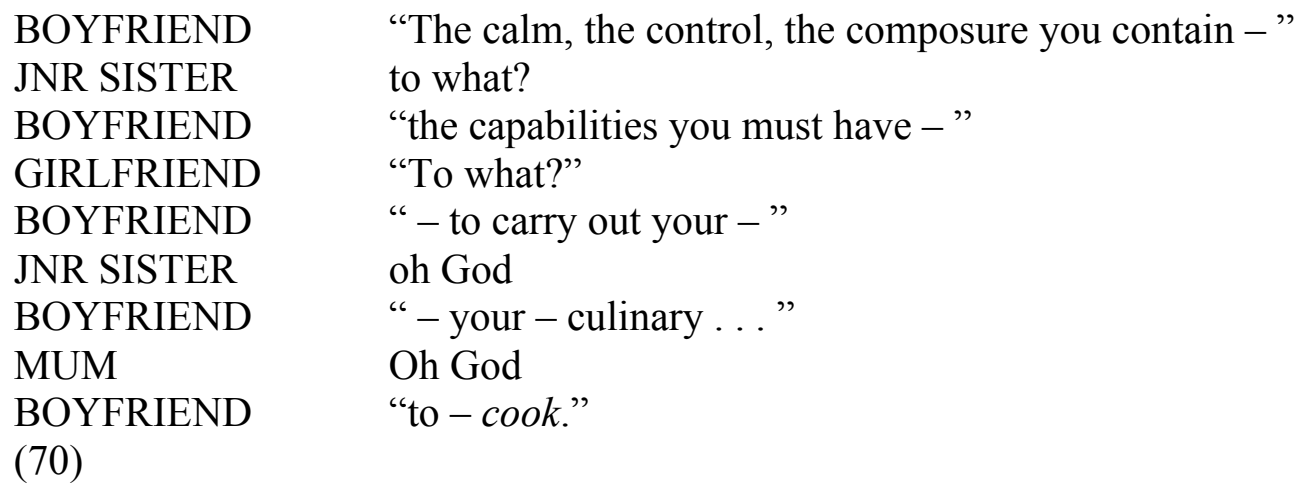

In this scene, the women provide the chorus in a call and response structure that approaches the patterns of song. Grandma goes on to echo Boyfriend's alliteration, using "cooker", "cookless", "coached", and "cook" (72), while Mum alliterates the fricative: "This is how your Father's flirting first started with me" (73). Words cease to function as vehicles of meaning and become pure sounds, combined for their tonal pleasures rather than their semantic efficacy. Critics have celebrated these aural qualities in tucker green's work. Citing Walter Pater, Alastair Macauley writes that her plays aspire to the condition of music; of born bad, specifically, another critical response emphasised the "dense and heavily accented language that repeats, with internal rhymes and sprung rhythms, making it sound almost musical" (Cook). Of stoning mary responses suggested - more strongly and not altogether admiringly - that tucker green's “contrapuntal, jazz-style riff” (Woddis) was ill-suited for theatre, such that "[t]he script might actually work better as an opera libretto, enriched by 
melodies" (Bassett). Director Sacha Wares also affirms this comparison, speaking of her directorial role being to interpret the ellipses and dashes in the elaborately crafted scripts, as a conductor would realise a musical score. These various responses suggest that tucker green's words are stripped of their semantic freight. Instead, meaning emerges through the combination of sounds and embodied silences.

The slippage between language and music is fulfilled in the epilogue to generations, where the choir sings the South African national anthem, "Nkosi Sikelel' iAfrika" ("God Bless Africa"). The title of this song commands a divine blessing on the nation, and its sound may be popularly recognised as a song of resistance. However, it is given in Xhosa, Zulu and Sesotho, with no translation offered in the printed text. By deploying these multiple languages, tucker green further experiments with oral/aural modes that loosen the equivalence between sign and signifier. Without translation, the meaning of this elaborately aural act is occluded and it, too, becomes pure sound to an ignorant audience. The failure of Anglophone spectators to fully understand the song - like critics' inability to follow the melodies of the characters' demotic speech - renders such an audience unable to respond. This barrier to engagement at first appears to undermine tucker green's political impulse, which is implicit in her attention to topics of contemporary importance. Yet, her careful demonstration of the failure of communication has its own political significance. Rather than attempting to deliver contextual understanding and cross-cultural empathy, I would argue that the deliberate opacity of tucker green's plays provocatively exposes the impossibility of such aims.

debbie tucker green's work is certainly conscious of mobilising its audiences. She deploys hyper-realist modes, which critique the realist suspension of disbelief and return the audience to an awareness of themselves and the illusion of the play. The subtitles in stoning mary function to this end; the 2007 production of generations offers another example, as spectators were seated on uncomfortable milk crates and stools circling the Young Vic studio's central playing area. random goes further beyond realism, as the single performer directly confronts her audience without the cushioning effect of any other characters, stage setting or props. tucker green's earlier plays, born bad, stoning mary and generations, explore the problematic lack of witnesses through protracted silences and frenetic dialogue that prevents characters from speaking and being heard. Conversely, the solo performer makes random monologic. The opening polyphony of family voices gradually gives way to quiet. Dad takes the phone off the hook, while Mum retreats into a self-censoring grief: "I don't got nuthin nice to say. / Nu'un polite / nu'un / broadcastable" (42). Only Sister continues to speak, although her words go unheard by all except the audience: "Dad don't wanna know" 
(47). By mandating that one performer plays multiple roles, tucker green emphasises the characters' interconnectivity. At the same time, this casting mandate cleverly exaggerates the failure of communication: the various characters are unable to inhabit the stage simultaneously, and so struggle to hear or speak to each other.

Clearly, tucker green resists any imperative to make the topics of her work explicit. Mirroring the deferred gratification of the central meal in generations, which tantalises the audience with its scent yet is never eaten even by the characters, so her use of language deliberately declines to match its locutionary work with a fulfilment of its semantic potential. Much goes unsaid, as in the active silences; even more goes unheard, as when characters' speech overlaps or languages other than English are used without translation. The traumas providing tucker green's subject matter translate into both deafening silence and incomprehensible noise. Finally, they are most fully expressed by the very fact of ruptured communication: these experiences are precisely unspeakable. tucker green may be named amongst the most lauded of today's black British playwrights, but her vital subject matter and its vivid delivery place her plays above this parochial category and alongside any great writing that attends to issues of justice and global in/equality.

In another of tucker green's productions, dirty butterfly, she returns to the topic of domestic abuse. The staging of this particular play provides a final provocative metaphor for tucker green's political agenda. Jo is subjected to daily attacks, and challenges her two neighbours to intervene. Neither Jason nor Amelia witness the act visually; Amelia sleeps downstairs to escape the noise, while Jason is guiltily captivated by the sounds. As tucker green's audiences, neither do we see the central subject of her plays: the violent acts that shape her drama are never depicted outright. Yet, we hear about them. This is enough to make us, like Jason and Amelia, complicit. What greater guilt than to passively endorse the crime and what else is Jason but an embedded representation of the theatre audience, entertained by pressing an ear to the wall beyond which another's suffering is played out? 


\section{List of Works Cited}

Agyekum, Kofi. “The Communicative Role of Silence in Akan.” Pragmatics 12.1 (2002): 3151.

Bassett, Kate. Rev. of Stoning Mary (10 Apr. 2005), dir. Marianne Elliott. Theatre Record XXV (2005): 426.

Billington, Michael. Rev. of Random (11 Mar. 2008), dir. Sacha Wares. Theatre Record XXVIII (2008): 284.

Cavendish, Dominic. Rev. of Dirty Butterfly (4 Mar. 2003), dir. Rufus Norris. Theatre Record XXIII (2003): 248+.

Cook, Mark. Rev. of Born Bad (7 May 2003), dir. Kathy Burke. Theatre Record XXIII (2003): 548.

Coghlan, Alexandra. "Rev. of Stoning Mary, dir. Lee Lewis." Time Out Sydney. 11 June 2008. <http://www.au.timeout.com/sydney/theatre/features/2354/stoning-mary>

De Jongh, Nicholas. Rev. of Random (11 Mar. 2008), dir. Sacha Wares. Theatre Record XXVIII (2008): 284.

Fragkou, Marissia. "'Silent Witness': Ethics of Responsibility in the Plays of Debbie Tucker Green." Contemporary British Theatre: Towards a New Canon Conference. Birmingham City University, Birmingham. 16 Oct. 2010.

Gardner, Lyn. "I Was Messing About [Interview with Debbie Tucker Green]." Guardian. March 2005. <http://www.theguardian.com/stage/2005/mar/30/theatre>

Goddard, Lynette. "'Death Never Used to Be for the Young': Grieving Teenage Murder in Debbie Tucker Green's Random." Women: A Cultural Review 20.3 (2009): 299-309.

---. "Politics of Form in Debbie Tucker Green's Plays." Contemporary British Theatre: Towards a New Canon Conference. Birmingham City University, Birmingham. 16 Oct. 2010.

Griffin, Gabriele. "Writing the Body: Reading Joan Riley, Grace Nichols and Ntozake Shange." Black Women's Writing. Ed. Gina Wisker. Basingstoke: Macmillan, 1993. 1942 .

Johns, Ian. Rev. of Dirty Butterfly (6 Mar. 2003), dir. Rufus Norris. Theatre Record XXIII (2003): 251-2.

Johns, Lindsay. "Black Theatre Is Blighted by Its Ghetto Mentality." London Evening Standard, 9 Feb. 2010. <http://www.standard.co.uk/news/black-theatre-is-blighted-byits-ghetto-mentality-6709941.html $>$

Letts, Quentin. Daily Mail. Rev. of Generations (2 Mar. 2007), dir. Sacha Wares. Theatre Record XXVII (2007): 236.

---. Rev. of Random (11 Mar. 2008), dir. Sacha Wares. Theatre Record XXVIII (2008): 284.

---. Rev. of Stoning Mary (6 Apr. 2005), dir. Marianne Eliott. Theatre Record XXV (2005): 425.

Macauley, Alastair. Rev. of Generations (2 Mar. 2007), dir. Sacha Wares. Theatre Record XXVII (2007): 235. 
Nathan, John. Rev. of Random (21 Mar. 2008), dir. Sacha Wares. Theatre Record XXVIII (2008): 287.

Osborne, Deirdre. "Debbie Tucker Green and Dona Daley: Two Neo-Millennial Black British Women Playwrights." Antares 4 (2010): 25-55.

Royal Court. "The Laws of War". Royal Court. n.d. $<$ http://www.royalcourttheatre.com/whats-on/cries-from-the-heart-2010-presents-thelaws-of-war>

---. Random [flyer]. London: Royal Court, 2010.

Scarry, Elaine. The Body in Pain: The Making and Unmaking of the World. Oxford: Oxford UP, 1985.

Shore, Robert. Rev. of Dirty Butterfly (5 Mar. 2003), dir. Rufus Norris. Theatre Record XXIII (2003): 251.

Sierz, Aleks. Rewriting the Nation: British Theatre Today. London: Methuen, 2011.

---. "Interview with Sacha Wares." Theatre Voice. Tribune, 2010. $<\mathrm{http}$ //www.theatrevoice.com/2243/director-sacha-wares-on-random/>

---. Rev. of Random (21 Mar. 2008), dir. Sacha Wares. Theatre Record XXVIII (2008): 287.

---. "If You Hate the Show, at Least You Have Passion [Interview with Debbie Tucker Green]." Independent. Apr. 2003. <http://www.inyerface-theatre.com/archive9.html\#d >

Sifianou, Maria. "Silence and politeness in silence: Interdisciplinary perspectives." Studies in Anthropological Linguistics 10. Ed. Adam Jaworski. Berlin: Mouton de Gruyter, 1997. 63-84.

The Agency. "Debbie Tucker Green". TheAgency.co.uk. The Agency, n.d. $<\mathrm{http}$ //www.theagency.co.uk/clients/clientdisplay.html?viewListing=MTcy $>$

tucker green, debbie. Random. London: Nick Hern, 2008. Print.

---. Stoning Mary. London: Nick Hern, 2005. Print.

---. Trade \& Generations: Two Plays. London: Nick Hern, 2005. Print.

---. Born Bad. London: Nick Hern, 2003. Print.

---. She Three. 1999. MS TTC/5/1/119. Theatre and Performance Collections, Victoria and Albert Museum, London.

Urban, Ken. "Cruel Brittania." Cool Britannia?: British Political Drama in the 1990s. Ed. Rebecca D'Monté and Graham James Saunders. Basingstoke: Palgrave Macmillan, 2008. 38-55.

Woddis, Carol. Rev. of Stoning Mary (10 Apr. 2005), dir. Marianne Elliott. Theatre Record XXV (2005): 426-7. 